\title{
New and improved infrared absorption cross sections for dichlorodifluoromethane (CFC-12)
}

\author{
J. J. Harrison ${ }^{1,2}$ \\ ${ }^{1}$ Department of Physics and Astronomy, University of Leicester, University Road, Leicester LE1 7RH, UK \\ ${ }^{2}$ National Centre for Earth Observation, University of Leicester, University Road, Leicester LE1 7RH, UK \\ Correspondence to: J. J. Harrison (jh592@leicester.ac.uk)
}

Received: 18 February 2015 - Published in Atmos. Meas. Tech. Discuss.: 16 March 2015

Revised: 9 July 2015 - Accepted: 10 July 2015 - Published: 12 August 2015

\begin{abstract}
Despite its widespread commercial use throughout the twentieth century, primarily in the refrigeration industry, dichlorodifluoromethane (CFC-12) is now known to have the undesirable effect of depleting stratospheric ozone. As this long-lived molecule slowly degrades in the atmosphere, monitoring its vertical concentration profile using infrared sounders on satellite platforms crucially requires accurate laboratory spectroscopic data. This work describes new high-resolution infrared absorption cross sections of dichlorodifluoromethane over the spectral range $800-1270 \mathrm{~cm}^{-1}$, determined from spectra recorded using a high-resolution Fourier transform spectrometer (Bruker IFS $125 \mathrm{HR}$ ) and a $26 \mathrm{~cm}$ pathlength cell. Spectra of dichlorodifluoromethane/dry synthetic air mixtures were recorded at resolutions between 0.01 and $0.03 \mathrm{~cm}^{-1}$ (calculated as 0.9/MOPD; MOPD = maximum optical path difference) over a range of temperatures and pressures (7.5-761 Torr and 190-294 K) appropriate for atmospheric conditions. This new cross-section dataset improves upon the one currently available in the HITRAN and GEISA databases.
\end{abstract}

\section{Introduction}

Modern civilisation owes much to refrigeration, from medical applications such as the preservation of tissues and organs, and the manufacture and transport of drugs, to the air conditioning of vehicles, homes, offices, and factories, and the manufacture, storage, and transport of food. It was the food industry which provided the driving force for refrigeration technologies in the late nineteenth and early twentieth centuries; storing perishable foodstuffs of animal and plant origin at low temperatures reduces bacterial growth, thus minimising the chances of contracting food-borne illnesses (Rees, 2013). Such innovative technologies allowed food to be transported vast distances from source to consumer, e.g. the first commercially successful transportation of refrigerated meat by sea from New Zealand to the United Kingdom on-board the Dunedin in 1882, thus beginning the global refrigerated meat industry (Williscroft, 2007).

It was only a matter of time before artificial refrigeration as a method of food preservation entered the home, replacing the iceboxes, which, as the name suggests, required a reliable supply of ice. However, early refrigerators were large, expensive, and, by today's standards, unsafe due to the use of highly toxic, corrosive refrigerants, such as ammonia and sulfur dioxide, which often leaked. Consumers with an aversion to death by combustion or toxic gas inhalation resisted. The search for alternative refrigerants was on (Rees, 2013; Myers, 2007).

The discovery of chlorofluorocarbons as inexpensive, reliable, safe, and non-toxic refrigerants for use in the home was made by Thomas Midgley, Jr., Albert Henne, and Robert McNary, in a cooperative effort between Frigidaire, at the time owned by General Motors, and DuPont (Myers, 2007). The suitability of dichlorodifluoromethane, also known as CFC12 or Freon-12 (Freon being a trade name of DuPont), as a refrigerant was discovered by this team in 1928 . The Kinetic Chemical Company was formed in 1930 to produce CFC-12 and develop other refrigerants. By the end of the 1930s, millions of smaller, lighter, less expensive, and above all safer refrigerators that used CFC-12 had found their way into the homes and hearts of consumers (Myers, 2007). 
The uses for CFCs climbed steadily worldwide over the following decades; in addition to refrigerants for refrigerators and air conditioners, they were used, for example, as aerosol propellants, blowing agents, and solvents. This steady climb in production was matched by a rise in their atmospheric concentrations. Their uses might have been many and varied, but in the end CFCs were too good to be true. In the early 1970s Rowland and Molina (1974) hypothesised that long-lived organic halogen compounds, such as the CFCs, could reach the stratosphere where they are dissociated by ultraviolet radiation to release chlorine atoms, which catalyse the destruction of stratospheric ozone. A decade later measurements of stratospheric ozone (Solomon, 1999) revealed that this was indeed the case; human activity was seriously damaging the ozone layer. This prompted international action and the ratification of the 1987 Montreal Protocol (and its later amendments), which aimed to phase out the worldwide production and use of CFCs and other ozonedepleting substances (ODSs). Although CFC production has now ceased, CFCs are still emitted into the atmosphere from existing "banks" (e.g. old refrigerators and air conditioners containing $\mathrm{CFCs}$ ), which are not regulated by the protocol (Harris et al., 2014). Releases from such banks currently dominate emissions for many ODSs, including CFC-12, the focus of the present study.

Dichlorodifluoromethane is currently the most abundant CFC in the Earth's atmosphere and the single largest contributor to the atmospheric loading of chlorine. It has an ozone depletion potential of 0.73 and a long atmospheric lifetime of 102 years (Harris et al., 2014). Additionally, it is a very strong greenhouse gas with a 100 -year global warming potential of 10300 (Harris et al., 2014). It is unsurprising, therefore, that there is much work carried out in monitoring CFC-12 atmospheric concentrations, particularly as its decline is linked to stratospheric ozone recovery. For example, according to in situ ground-based AGAGE (Advanced Global Atmospheric Gases Experiment) measurements, the CFC-12 annual mean mole fraction peaked at $544.2 \mathrm{ppt}$ in 2003 (Clerbaux et al., 2007), decreasing to 527.5 ppt by 2012 (Carpenter et al., 2014).

Measurements of CFC-12 in the atmosphere are also made using remote-sensing techniques. There are a number of such datasets available, three of these from measurements taken by instruments deployed on the space shuttle: ATMOS (Atmospheric Trace MOlecule Spectroscopy) (Chang et al., 1996; Irion et al., 2002), CIRRIS 1A (Cryogenic InfraRed Radiance Instrumentation for Shuttle) (Bingham et al., 1997), and CRISTA (CRyogenic Infrared Spectrometers and Telescopes for the Atmosphere) (Offermann et al., 1999). Most datasets are derived from measurements taken by instruments on satellites: the CLAES (Cryogenic Limb Array Etalon Spectrometer) instrument on UARS (Upper Atmosphere Research Satellite) (Nightingale, et al., 1996), the ILAS (Improved Limb Atmospheric Spectrometer) instrument on ADEOS (ADvanced Earth Observing Satel- lite) (Khosrawi et al., 2004) and the follow-up ILAS II on ADEOS II (Wetzel et al., 2006), the HIRDLS (HIgh Resolution Dynamics Limb Sounder) instrument on Aura (Hoffmann et al., 2014), the MIPAS (Michelson Interferometer for Passive Atmospheric Sounding) instrument on ENVISAT (ENVIronmental SATellite) (e.g. Hoffmann et al., 2005; Dinelli et al., 2010; Kellmann et al., 2012), and the ACE-FTS (Atmospheric Chemistry Experiment - Fourier transform spectrometer) instrument on SCISAT (Brown et al., 2013).

All these remote-sensing datasets have one thing in common: they crucially rely on the accuracy of the underlying laboratory spectroscopy used in the forward model. Errors in the spectroscopy lead directly to errors in the retrieved data products, so it is important that the laboratory measurements are as accurate as possible. Furthermore, since the dichlorodifluoromethane infrared (IR) spectrum consists of an abundance of densely packed lines, it is a virtually impossible task to derive spectroscopic line parameters for this molecule. The solution for remote-sensing purposes, therefore, is to derive absorption cross sections from airbroadened spectra recorded in the laboratory. In order to be most useful for remote sensing, these cross-section datasets require (1) accurate band intensities, (2) accurate wavenumber scales, (3) a wide coverage of atmospherically relevant pressure-temperature (PT) combinations, and (4) spectra recorded at an appropriate resolution (Doppler-limited at the lowest pressures). This work presents new spectroscopic data which improve upon those currently available in the HITRAN and GEISA databases. In Sect. 2, a discussion of previous CFC-12 IR absorption cross-section datasets, derived from laboratory measurements, is presented. Section 3 provides details on the new measurements taken as part of this work and the derivation of cross sections, with Sect. 4 providing a discussion of the results and comparison with previous measurements.

\section{Previous quantitative spectroscopic measurements of dichlorodifluoromethane}

Two stable isotopes of chlorine are found in nature, ${ }^{35} \mathrm{Cl}$ and ${ }^{37} \mathrm{Cl}$, with abundances of $\sim 76$ and $\sim 24 \%$ respectively so it is no surprise that there are a number of dichlorodifluoromethane isotopologues, namely, $\mathrm{C}^{35} \mathrm{Cl}_{2} \mathrm{~F}_{2}, \mathrm{C}^{35} \mathrm{Cl}^{37} \mathrm{Cl}_{2}$, and $\mathrm{C}^{37} \mathrm{Cl}_{2} \mathrm{~F}_{2}$, with approximate abundances of 57,36 , and $6 \%$ respectively. $\mathrm{C}^{35} \mathrm{Cl}^{37} \mathrm{C}_{1} \mathrm{~F}_{2}$, the asymmetric isotopologue, has $C_{\mathrm{s}}$ symmetry, while the other two symmetric species have $C_{2 \mathrm{v}}$ symmetry (McNaughton et al., 1994; D'Amico et al., 2002). Dichlorodifluoromethane, which is an asymmetric top, has nine fundamental vibrational modes, and the $800-1270 \mathrm{~cm}^{-1}$ spectral range covered in the present work contains four main band systems: the fundamental bands $v_{6} \sim 923 \mathrm{~cm}^{-1}, v_{1} \sim 1101 \mathrm{~cm}^{-1}$, and $\nu_{8} \sim 1161 \mathrm{~cm}^{-1}$ and the combination band $\nu_{3}+v_{7} \sim 888 \mathrm{~cm}^{-1}$, which owes 


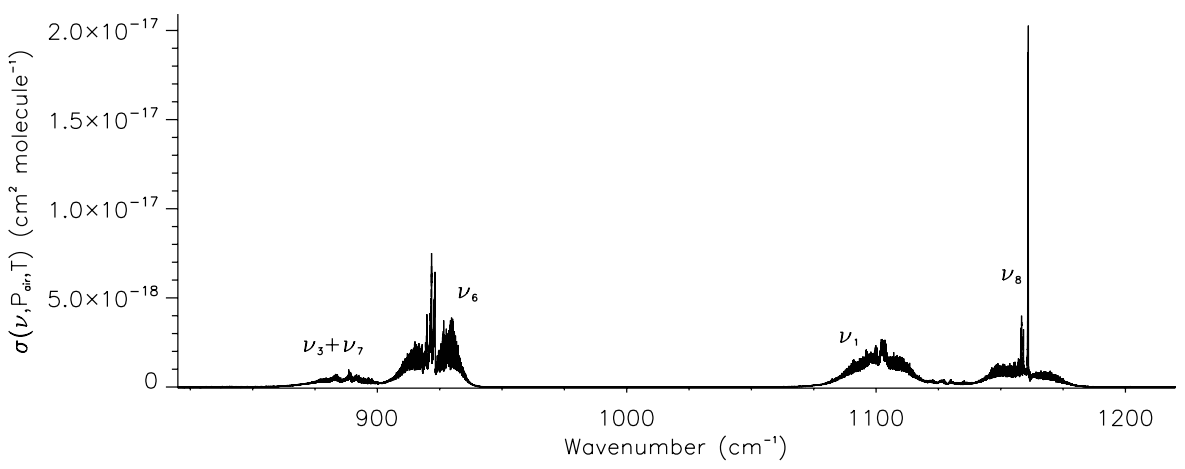

Figure 1. The IR absorption cross section of dichlorodifluoromethane/dry synthetic air at $268.9 \mathrm{~K}$ and 7.54 Torr, with vibrational band assignments over the spectral range covered in this work.

its intensity largely to a Fermi resonance with $v_{6}$. Note that these frequencies are for the most abundant isotopologue, $\mathrm{C}^{35} \mathrm{Cl}_{2} \mathrm{~F}_{2}$, and that the modes are numbered according to the $x, y, z$ axis system convention outlined in D'Amico et al. (2002). Figure 1 provides a plot of the new absorption cross section at $268.9 \mathrm{~K}$ and 7.54 Torr with these main band systems labelled. Full details on the measurement conditions and derivation of this cross section are given in Sect. 3.

The HITRAN 1986 compilation (Rothman et al., 1987) included for the first time high-resolution cross sections for a first approximation simulation of the spectra of a number of important atmospheric molecules, including CFC-12, for which no line parameters were available. The cross sections were derived from laboratory absorption spectra of pure samples recorded at $296 \mathrm{~K}$ at the University of Denver (Massie et al., 1985). The quoted accuracy of the data was of the order of $10-25 \%$.

Around this time there were many measurements of CFC12 IR band strengths (e.g. Varanasi and Ko, 1977; Kagann et al., 1983; Varanasi and Chudamani, 1988; Nguyen et al, 1986). However it was not until 1991 that temperaturedependent cross sections for CFC-12 appeared (McDaniel et al., 1991); these were derived from measurements of pure CFC-12 at $0.03 \mathrm{~cm}^{-1}$ resolution and 203, 213, 233, 253, 273, and $293 \mathrm{~K}$. This dataset was introduced into the HITRAN 1991/1992 compilation (Rothman et al., 1992; Massie and Goldman, 1992).

A comprehensive CFC-12 cross-section dataset, derived from measurements of $\mathrm{N}_{2}$-broadened CFC-12 over a range of temperatures down to $200 \mathrm{~K}$ at spectral resolutions between 0.01 and $0.03 \mathrm{~cm}^{-1}$, was published in 1994 (Varanasi and Nemtchinov, 1994). According to the official HITRAN 1996 publication (Rothman et al., 1996), only cross sections for 15 of these PT combinations (temperatures ranging from 216 to $296 \mathrm{~K}$ and pressures from 170 to 760 Torr) were included in the compilation. However, in HITRAN 2000 (Rothman et al., 2003) this had increased to 52 PT combinations covering temperatures from 190 to $296 \mathrm{~K}$ and 8 to $760 \mathrm{Torr}$, the reference for these being a private commu- nication from P. Varanasi (2000); each PT combination is spread across two wavenumber ranges, 850-950 and 1050$1200 \mathrm{~cm}^{-1}$. This dataset has remained unchanged for subsequent HITRAN compilations, including the most recent HITRAN 2012 (Rothman et al., 2013), and was also included in the most recent GEISA 2003 (Jacquinet-Husson et al., 2005) and 2009 (Jacquinet-Husson et al., 2011) compilations. It has been used extensively for atmospheric remote-sensing applications over the last decade and a half. The present study has identified a number of deficiencies with the Varanasi dataset; these will be fully discussed in Sect. 4 .

\section{New absorption cross sections of air-broadened dichlorodifluoromethane}

\subsection{Experimental}

All air-broadened dichlorodifluoromethane IR spectra were recorded at the Molecular Spectroscopy Facility, Rutherford Appleton Laboratory, UK, using a Bruker Optics IFS 125 HR FTS operated by Bruker's OPUS software (refer to https://www.bruker.com/ products/infrared-near-infrared-and-raman-spectroscopy/ opus-software/overview.html for information on the software). The FTS instrumental parameters and settings are summarised in Table 1. Spectra were recorded at resolutions between 0.01 and $0.03 \mathrm{~cm}^{-1}$ (defined as the Bruker instrument resolution of $0.9 / \mathrm{MOPD}$; MOPD $=$ maximum optical path difference), depending on the total pressure of the mixture - see Table 2. Due to the nonlinear response of mercury cadmium telluride detectors to the detected radiation, which results in baseline perturbations, all interferograms were transformed using the nonlinearity correction in Bruker's OPUS software.

The experimental setup is similar to that described previously for related measurements (Harrison et al., 2010; Harrison, 2015). Briefly, all measurements utilised a $26 \mathrm{~cm}$ pathlength single-pass stainless-steel absorption cell, with 
Table 1. FTS parameters and cell configuration for all measurements.

\begin{tabular}{ll}
\hline Mid-IR source & Globar \\
\hline Detector & Mercury cadmium telluride (MCT) D313 \\
Beam splitter & Potassium bromide (KBr) \\
Optical filter & $\sim 700-1700 \mathrm{~cm}^{-1}$ bandpass \\
Spectral resolution & $0.01-0.03 \mathrm{~cm}^{-1}$ \\
Aperture size & $3.15 \mathrm{~mm}$ \\
Apodisation function & Boxcar \\
Phase correction & Mertz \\
Cell windows & Potassium bromide $(\mathrm{KBr})$ \\
Pressure gauges & $3 \mathrm{MKS}-690 \mathrm{~A}$ Baratrons \\
& $(1,10$, and 1000 Torr) $( \pm 0.05 \%$ accuracy) \\
Thermometry & 4 PRTs, Labfacility IEC 751 Class A \\
\hline
\end{tabular}

wedged $\mathrm{KBr}$ windows sealed on sprung PTFE O-rings. The cell was mounted inside the sample compartment of the FTS, which was evacuated to $<0.2 \mathrm{~Pa}$. Sample temperatures below room temperature were achieved using a Julabo cooler with ethanol coolant circulating through the outer jacket of the cell.

The cell temperature was monitored by four platinum resistance thermometers (PRTs) in thermal contact at different points on the exterior surface of the cell. For the majority of measurements the temperature gradient within the cell was below $0.5 \mathrm{~K}$, although this was closer to $1.0 \mathrm{~K}$ for the lowest temperatures. A Pfeiffer turbomolecular pump (CompactTurbo TMH $071 \mathrm{P}$ ), backed by a Leybold rotary vane pump (Trivac D8B), was attached to the cell and used to evacuate it prior to preparing each sample; the baseline vacuum pressure was $<0.001$ Torr. For all measurements, dichlorodifluoromethane (Matheson, 99.9\% minimum purity, natural-abundance isotopic mixture) was used "as is" without additional purification, as was the dry synthetic air ("Air Zero", BOC, total hydrocarbons $<3 \mathrm{ppm}, \mathrm{H}_{2} \mathrm{O}<2 \mathrm{ppm}$, $\mathrm{CO}_{2}<1 \mathrm{ppm}, \mathrm{CO}<1 \mathrm{ppm}$ ). Sample mixtures were prepared by introducing dichlorodifluoromethane directly into the cell and then adding dry synthetic air. Pressures were measured close to the cell inlet using Baratron capacitance manometers (MKS). Details of the sample pressures and temperatures, and their experimental uncertainties, are contained in Table 2. Multiple interferograms were recorded at each PT combination in order to improve the signal-to-noise ratio (SNR), with empty cell background interferograms recorded before and after these sample measurements. Pure nitrous oxide $\left(\mathrm{N}_{2} \mathrm{O}\right)$ spectra were additionally recorded at each temperature to calibrate the wavenumber scale.

\subsection{Determination of absorption cross sections for dichlorodifluoromethane}

Measured interferograms were Fourier transformed using Bruker's OPUS software, and transmittance spectra were calculated directly as $I_{\text {sample }} / I_{\text {background. }}$. The wavenumbers
Table 2. Summary of the sample conditions for all measurements.

\begin{tabular}{|c|c|c|c|}
\hline $\begin{array}{l}\text { Temperature } \\
(\mathrm{K})\end{array}$ & $\begin{array}{c}\text { Initial } \mathrm{CCl}_{2} \mathrm{~F}_{2} \\
\text { Pressure } \\
\text { (Torr) }^{\mathrm{a}}\end{array}$ & $\begin{array}{l}\text { Total Pressure } \\
\text { (Torr) }\end{array}$ & $\begin{array}{l}\text { Spectral } \\
\text { resolution } \\
\left(\mathrm{cm}^{-1}\right)^{b}\end{array}$ \\
\hline $189.5 \pm 0.8$ & 0.1046 & $7.53 \pm 0.01$ & 0.01 \\
\hline $189.5 \pm 0.8$ & 0.1324 & $38.0 \pm 0.1$ & 0.01 \\
\hline $189.5 \pm 0.8$ & 0.1358 & $170.4 \pm 0.4$ & 0.03 \\
\hline $200.4 \pm 0.4$ & 0.0972 & $7.67 \pm 0.08$ & 0.01 \\
\hline $200.4 \pm 0.4$ & 0.1036 & $37.6 \pm 0.1$ & 0.01 \\
\hline $200.3 \pm 0.4$ & 0.1281 & $75.0 \pm 0.2$ & 0.01 \\
\hline $200.6 \pm 0.4$ & 0.1386 & $170.4 \pm 0.2$ & 0.03 \\
\hline $200.4 \pm 0.4$ & 0.1295 & $281.3 \pm 0.3$ & 0.03 \\
\hline $216.1 \pm 0.2$ & 0.1450 & $7.54 \pm 0.01$ & 0.01 \\
\hline $216.1 \pm 0.3$ & 0.1301 & $37.3 \pm 0.1$ & 0.01 \\
\hline $216.1 \pm 0.2$ & 0.1350 & $75.4 \pm 0.2$ & 0.01 \\
\hline $216.2 \pm 0.3$ & 0.1511 & $129.4 \pm 0.2$ & 0.02 \\
\hline $216.2 \pm 0.2$ & 0.1356 & $280.9 \pm 0.5$ & 0.03 \\
\hline $216.2 \pm 0.2$ & 0.1160 & $379.5 \pm 0.6$ & 0.03 \\
\hline $233.1 \pm 0.1$ & 0.1210 & $7.50 \pm 0.01$ & 0.01 \\
\hline $233.1 \pm 0.1$ & 0.1513 & $37.7 \pm 0.1$ & 0.01 \\
\hline $233.1 \pm 0.1$ & 0.1492 & $75.7 \pm 0.1$ & 0.01 \\
\hline $233.1 \pm 0.2$ & 0.1226 & $197.2 \pm 0.4$ & 0.03 \\
\hline $233.2 \pm 0.2$ & 0.1612 & $380.8 \pm 0.4$ & 0.03 \\
\hline $244.9 \pm 0.1$ & 0.1599 & $7.49 \pm 0.01$ & 0.01 \\
\hline $244.9 \pm 0.1$ & 0.1538 & $50.8 \pm 0.1$ & 0.01 \\
\hline $244.8 \pm 0.1$ & 0.1498 & $171.0 \pm 0.1$ & 0.03 \\
\hline $244.8 \pm 0.1$ & 0.1675 & $444.6 \pm 0.2$ & 0.03 \\
\hline $244.8 \pm 0.1$ & 0.1589 & $550.0 \pm 0.2$ & 0.03 \\
\hline $268.9 \pm 0.2$ & 0.1633 & $7.54 \pm 0.01$ & 0.01 \\
\hline $268.8 \pm 0.2$ & 0.1673 & $47.8 \pm 0.1$ & 0.01 \\
\hline $269.0 \pm 0.2$ & 0.1893 & $169.8 \pm 0.1$ & 0.03 \\
\hline $269.0 \pm 0.2$ & 0.1975 & $350.9 \pm 0.1$ & 0.03 \\
\hline $269.1 \pm 0.3$ & 0.1754 & $551.1 \pm 0.4$ & 0.03 \\
\hline $269.0 \pm 0.2$ & 0.2000 & $759.4 \pm 0.5$ & 0.03 \\
\hline $294.2 \pm 0.2$ & 0.2210 & $350.5 \pm 0.2$ & 0.03 \\
\hline $293.7 \pm 0.1$ & 0.2080 & $761.0 \pm 0.6$ & 0.03 \\
\hline
\end{tabular}

${ }^{\mathrm{a}}$ MKS-690A Baratron readings are accurate to $\pm 0.05 \%$. ${ }^{\mathrm{b}}$ Using the Bruker definition of 0.9/MOPD.

were calibrated against the positions of isolated $\mathrm{N}_{2} \mathrm{O}$ absorption lines in the range $1140-1320 \mathrm{~cm}^{-1}$, taken from the HITRAN 2012 database (Rothman et al., 2013). The wavenumber accuracy of the wavenumber-calibrated dichlorodifluoromethane measurements is comparable to the accuracy of the selected $\mathrm{N}_{2} \mathrm{O}$ lines, which HITRAN error codes indicate is between 0.001 and $0.0001 \mathrm{~cm}^{-1}$ but is likely closer to $0.0001 \mathrm{~cm}^{-1}$.

According to the Beer-Lambert Law, transmittance $\tau(v$, $\left.P_{\text {air }}, T\right)$, at wavenumber $v\left(\mathrm{~cm}^{-1}\right)$, temperature $T(\mathrm{~K})$, and synthetic air pressure $P_{\text {air }}$, can be related to the absorption cross section, $\sigma\left(v, P_{\text {air }}, T\right)$ with units $\mathrm{cm}^{2}$ molecule ${ }^{-1}$,

$\sigma\left(v, P_{\text {air }}, T\right)=-\frac{10^{4} k_{\mathrm{B}} T}{P l} \ln \tau\left(v, P_{\text {air }}, T\right)$, 
where $P$ is the pressure of the absorbing gas $(\mathrm{Pa}), l$ is the optical pathlength $(\mathrm{m})$, and $k_{\mathrm{B}}$ is the Boltzmann constant $\left(=1.3806488 \times 10^{-23} \mathrm{~J} \mathrm{~K}^{-1}\right)$. Equation (1) was used to derive the initial absorption cross sections from the transmittance spectra. Integrated band strengths over the range 800$1270 \mathrm{~cm}^{-1}$ were then calculated for each of these cross sections and ratios taken against a "calibration standard" integrated band strength over the same spectral range; this was derived from two 760 Torr $\mathrm{N}_{2}$-broadened CFC-12 spectra (recorded at 278 and $298 \mathrm{~K}$ ) from the Pacific Northwest National Laboratory (PNNL) IR database (http://nwir.pnl.gov) (Sharpe et al., 2004). Final absorption cross sections were obtained by calibrating the $y$ axis, according to

$$
\frac{1.3491 \times 10^{-16} \mathrm{~cm} \mathrm{molecule}^{-1}}{\int_{800 \mathrm{~cm}^{-1}}^{1270 \mathrm{~cm}^{-1}} \sigma\left(v, P_{\mathrm{air}}, T\right) \partial v} \sigma\left(v, P_{\mathrm{air}}, T\right) .
$$

Note that each PNNL spectrum, recorded at $0.112 \mathrm{~cm}^{-1}$ spectral resolution, is a composite of multiple pathlengthconcentration burdens, and great care has been taken to ensure that sample concentrations have been determined accurately.

Previous experience with this experimental setup has revealed difficulties in characterising the absorber partial pressures during preparation of the mixtures (e.g. Harrison, 2013, 2015). The reasons for this are assumed to relate to issues with CFC-12 adsorption in the vacuum line and on the cell walls. The procedure used to calibrate the cross-section intensities assumes that the integrated intensity over each band system is independent of temperature. The reader is referred to the discussion in Harrison et al. (2010) for a more complete explanation of the underlying assumption and to references cited within Harrison (2015) for details on the successful use of this approach in the past. Note that the Varanasi CFC-12 cross sections do exhibit some scatter in integrated band intensity; however there is no evidence for any temperature dependence.

In order to obtain an estimate of the random errors in the absorption cross sections, many measurements need to be taken for each PT combination. Due to time constraints, however, only one spectrum has been recorded for each of these combinations, in the same manner as the Varanasi dataset. Despite this, it is expected that systematic errors make the dominant contribution to the uncertainty. Maximum uncertainties in the sample temperatures $\left(\mu_{T}\right)$ and total pressures $\left(\mu_{P}\right)$ are 0.4 and $0.2 \%$ respectively (Table 2$)$. The photometric uncertainty $\left(\mu_{\mathrm{phot}}\right)$ is estimated to be $\sim 2 \%$. The pathlength error $\left(\mu_{\text {path }}\right)$ is estimated to be negligibly small, lower than $0.1 \%$. According to the relevant metadata files in the PNNL database, the systematic error in the PNNL dichlorodifluoromethane spectra used for intensity calibration is estimated to be less than $3 \%(2 \sigma)$. Equating the error, $\mu_{\mathrm{PNNL}}$, with the $1 \sigma$ value, i.e. $1.5 \%$, and assuming that the error estimates for all quantities are uncorrelated, the overall system- atic error in the dataset can be calculated from

$\mu_{\text {systematic }}^{2}=\mu_{\mathrm{PNNL}}^{2}+\mu_{T}^{2}+\mu_{P}^{2}+\mu_{\mathrm{phot}}^{2}$.

Note that using PNNL spectra for intensity calibration effectively nullifies the errors in the dichlorodifluoromethane partial pressures and cell pathlength, so these do not have to be included in Eq. (3). According to Eq. (3), the systematic error contribution, $\mu_{\text {systematic }}$, to the new dichlorodifluoromethane cross sections is $\sim 3 \%$.

\section{Discussion and comparison of absorption cross-section datasets}

The SNRs of the new transmittance spectra, calculated by the OPUS software at $\sim 990 \mathrm{~cm}^{-1}$ where the transmittance is close to 1, range from 2000 to 3700 (rms). Without having access to the original Varanasi transmittance spectra and without knowledge of the absorber partial pressures, it is not possible to determine the same quantity for the Varanasi data. However, a direct comparison of those absorption cross sections at similar temperature and pressure reveal that the new cross sections possess on average improved SNRs. Additionally, a number of Varanasi cross sections, particularly those derived from spectra recorded at $0.01 \mathrm{~cm}^{-1}$ resolution at low temperature and pressure, contain channel fringes noticeably above the noise level (with an amplitude at most $\sim 1 \%$ in absorption, relative to the $\mathrm{Q}$ branch features near $\sim 923 \mathrm{~cm}^{-1}$ ); these are caused by reflections from e.g. windows in the optical path of the spectrometer. For the measurements described in the present work, care has been taken to prevent channelling by using wedged cell windows. The new spectra were recorded at spectral resolutions between 0.01 and $0.03 \mathrm{~cm}^{-1}$ (defined as 0.9/MOPD), based on the resolutions of the Varanasi measurements, which were deemed suitable; $0.01 \mathrm{~cm}^{-1}$ resolution was appropriate for low pressures in the Doppler-limited regime, with $0.03 \mathrm{~cm}^{-1}$ more suitable at higher pressures.

In order to compare integrated band strengths, integrals were taken over the ranges of the Varanasi cross-section files, 850-950 and $1050-1200 \mathrm{~cm}^{-1}$, covering the $v_{6} / \nu_{3}+v_{7}$ and $v_{1} / \nu_{8}$ bands respectively. Unfortunately, the wavenumber ranges of these earlier cross sections do not quite extend far enough to obtain a true measure of the baseline position for comparison with the new dataset. Note also that the files in HITRAN/GEISA have had all negative $y$ values set to 0 , which has the effect of adjusting the baseline positions by a small amount near the band wings, slightly increasing the integrated band strengths.

Figure 2 is a plot of integrated band strength (without error bars, for ease of comparison) against temperature for each dataset and wavenumber range. The Varanasi integrated band strengths at each temperature display a small spread in values. Although not explicitly identified in the figure, band strengths for measurements at pressures below 100 Torr are 


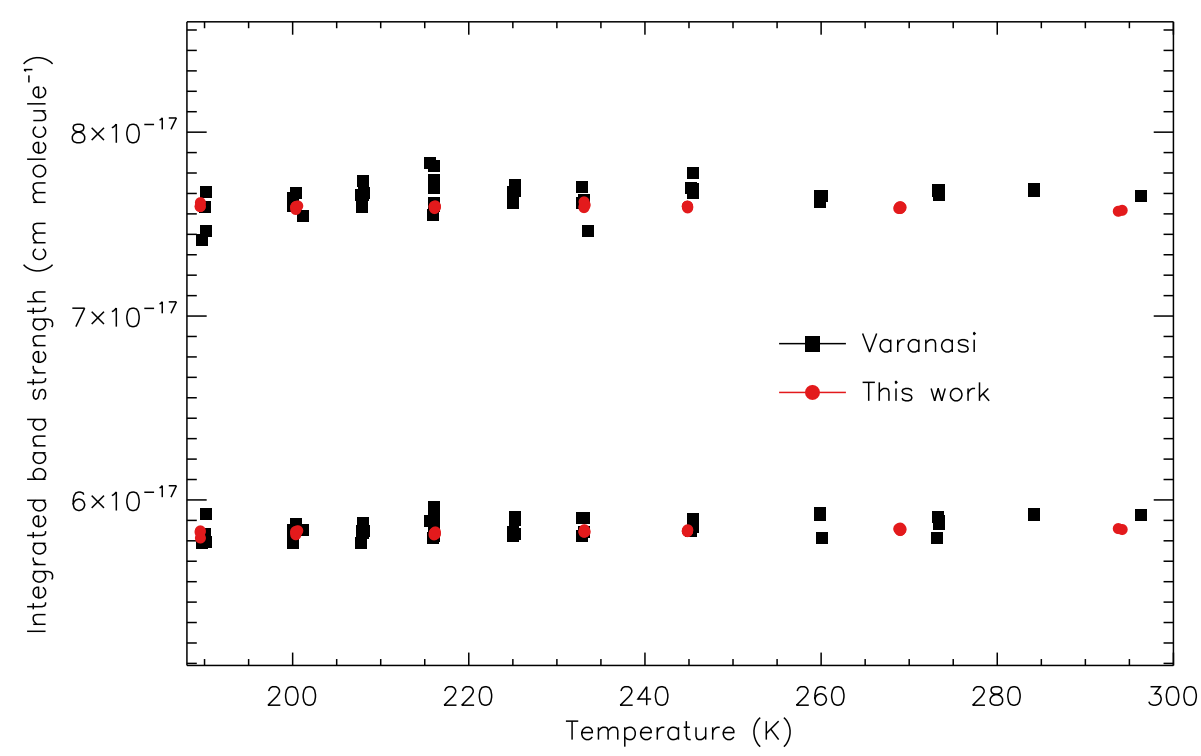

Figure 2. A plot of integrated band strength versus temperature for each of the datasets over the wavenumber ranges $850-950 \mathrm{~cm}^{-1}(\mathrm{bottom})$ and $1050-1200 \mathrm{~cm}^{-1}$ (top). The Varanasi data at each temperature display a small spread in values, most likely arising from calibration errors between sets of measurements taken at different times, and problems with dichlorodifluoromethane adsorption on cell walls. Refer to the text for a more detailed discussion.

on average $\sim 1-2 \%$ lower than those at higher pressures. One would not expect integrated band strengths to vary with pressure; there is certainly no statistically significant trend to indicate this is the case. Following the discussion in Sect. 2, it seems that the Varanasi measurements below 170 Torr were taken at a later date, so there could be some calibration error between measurement sets. Additionally, thermometry inaccuracies or CFC-12 adsorption on cell walls could play a role.

There is no information in the original publication of Varanasi and Nemtchinov (1994) regarding wavenumber calibration; however it is stated in the HITRAN 2000 publication (Rothman et al., 2003) that the wavenumber scales were calibrated using the absorption lines of ammonia, acetylene, carbon dioxide, methane, and nitrous oxide bands in the thermal IR $(7-14 \mu \mathrm{m})$ as given in HITRAN. Despite this, the wavenumber scale does not agree with that determined for the new dataset; in fact there is some variation in wavenumber scale from cross section to cross section. Figure 3 provides a comparison for two cross sections at similar experimental conditions $(\sim 216 \mathrm{~K}$ and $130 \mathrm{Torr})$, one from each dataset; the difference plot reveals particularly sharp features at $\sim 921.8$ and $923.2 \mathrm{~cm}^{-1}$, coinciding with the steepest part of the Q-branch features, a result of the Varanasi cross section shifted by $\sim 0.06 \mathrm{~cm}^{-1}$ (a correction factor of $\sim 1.000007$ ) to low wavenumber. This is in line with the wavenumber calibration errors observed for the 1,1,1,2-tetrafluoroethane (HFC-134a) Varanasi dataset (Harrison, 2015).
Although it is beyond the scope of this work to quantify numerically how the new dataset will improve atmospheric retrievals, the improvements in the new absorption crosssection dataset can be further illustrated with the aid of highresolution atmospheric spectra with strong CFC-12 absorption features, such as measured by the ACE-FTS (Bernath et al., 2005), and a simple comparison of spectral residuals, i.e. differences between observed atmospheric and calculated spectra, from v3.0 ACE-FTS processing.

Firstly, in ACE-FTS v3.0 processing the spectral residuals associated with the $v_{6}$ band reveal systematic features that cannot be accounted for in the forward model when using the Varanasi dataset (C. D. Boone, personal communication, 2012; Harrison, 2014). These features are very similar in appearance to the sharp features observed in Fig. 3, indicating that they arise from the poor wavenumber calibration of the Varanasi dataset. Note that for ACE-FTS retrievals the CFC-12 mixing ratios are adjusted in order to minimise the residuals (in the $v_{6}$ band) and that these sharp features are negative when residuals are calculated in transmittance. The improvement in wavenumber scale of the new cross sections has been verified using the ACE-FTS forward model and retrieval software on a limited selection of measurements (see slide 18 of Harrison, 2014; C. D. Boone, personal communication, 2014); in all cases the systematic features were minimised.

Secondly, ACE-FTS residuals associated with the very strong Q-branch features of the $v_{8}$ band are particularly large, so much so that the Varanasi data in this region cannot be used in ACE-FTS retrievals. This issue largely relates to the 


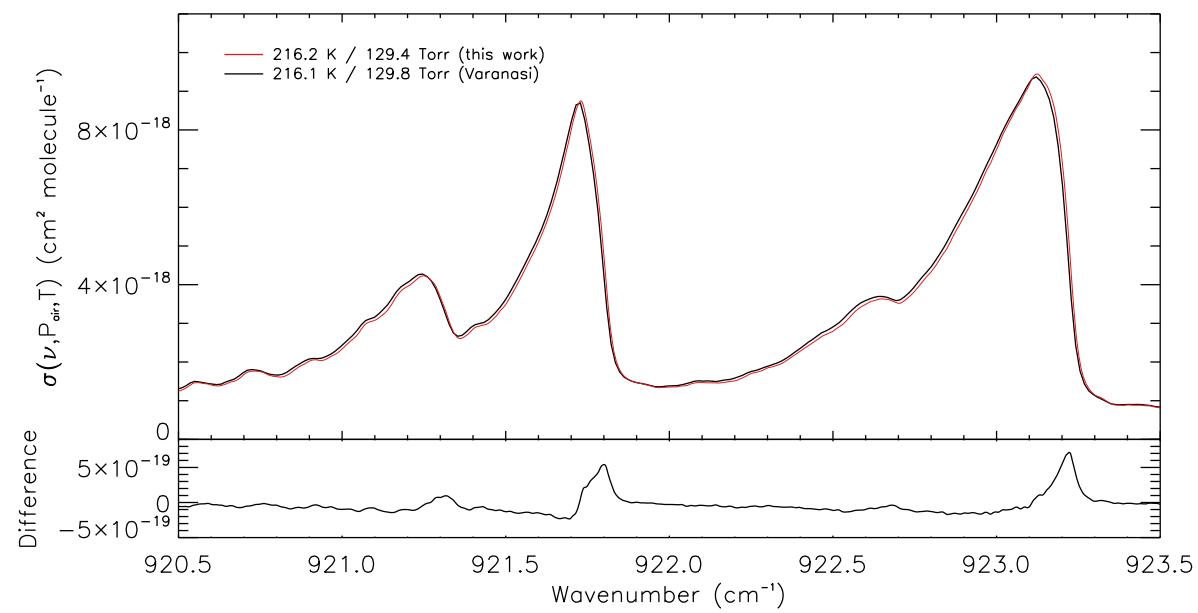

Figure 3. A comparison between two IR absorption cross sections of dichlorodifluoromethane/dry synthetic air at $216.2 \mathrm{~K} / 129.4 \mathrm{Torr}$ (new) and $216.1 \mathrm{~K} / 129.8$ Torr (Varanasi) in the vicinity of the $v_{6}$ band Q branches; the difference plot reveals sharp features coinciding with the steepest part of the Q-branch features, indicative of poor wavenumber calibration in the Varanasi cross section.

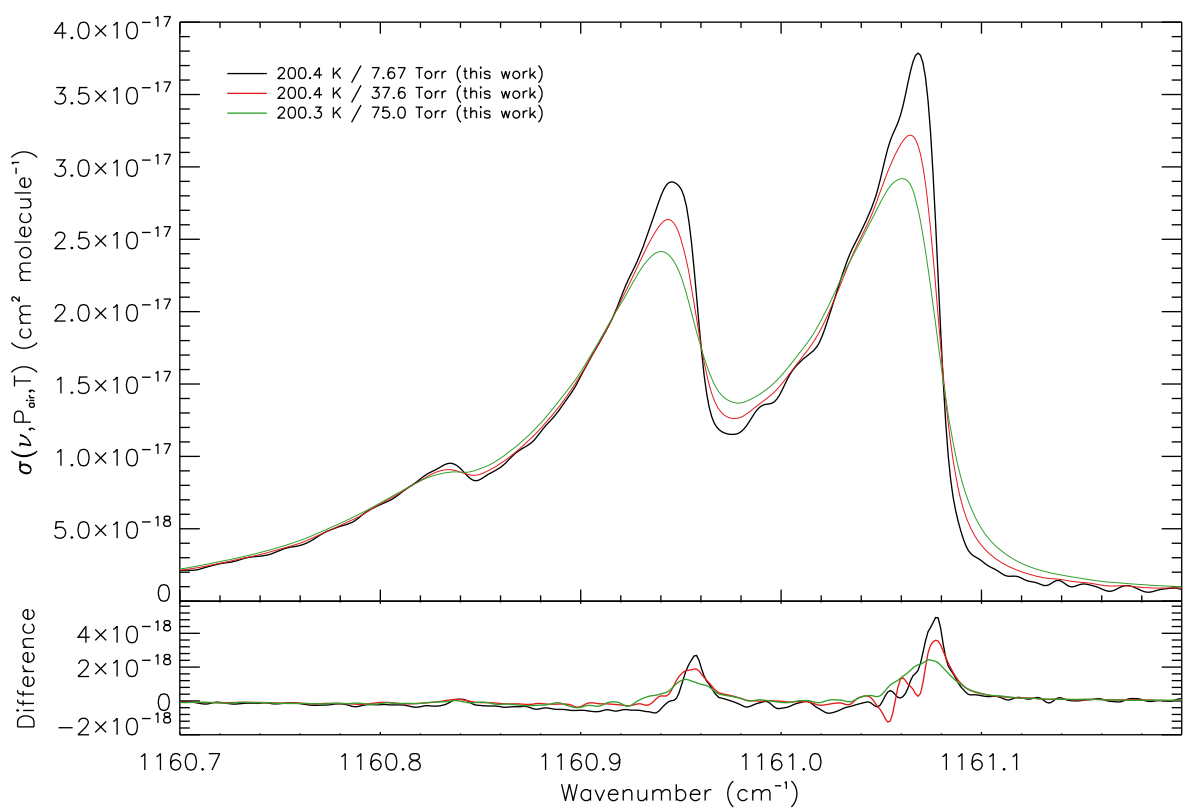

Figure 4. Three new IR absorption cross sections of dichlorodifluoromethane/dry synthetic air at $\sim 200 \mathrm{~K}$ (specifically $200.4 \mathrm{~K} / 7.67$ Torr, 200.4 K/37.6 Torr and 200.3 K/75.0 Torr) in the vicinity of the $\nu_{8}$ band Q branches near $1161 \mathrm{~cm}^{-1}$ and their differences from the Varanasi cross sections at similar PT (specifically 200.4 K/7.50 Torr, 200.0 K/37.7 Torr, and 200.0 K/75.6 Torr). The differences are larger than would be expected solely from the small discrepancies in experimental conditions; they largely result from the wavenumber calibration errors in the Varanasi cross sections.

wavenumber calibration errors already discussed and additionally to the saturation of the strongest features in some of the Varanasi measurements. Figure 4 provides a plot of three new cross sections at $\sim 200 \mathrm{~K}$ and their differences from the Varanasi cross sections at similar PT. Again, it has been verified using the ACE-FTS forward model for a limited selection of measurements that systematic features are minimised when using the new dataset (see slide 19 of Harrison, 2014; C. D. Boone, personal communication, 2014).

For a retrieval scheme in which the forward model uses absorption cross sections, the ideal situation is to interpolate between cross sections rather than extrapolate beyond them. Ideally the target pressure and temperature of an atmospheric spectrum should be bracketed with four cross sections, two of these at higher $T$ and two at lower $T$, and one each of these 


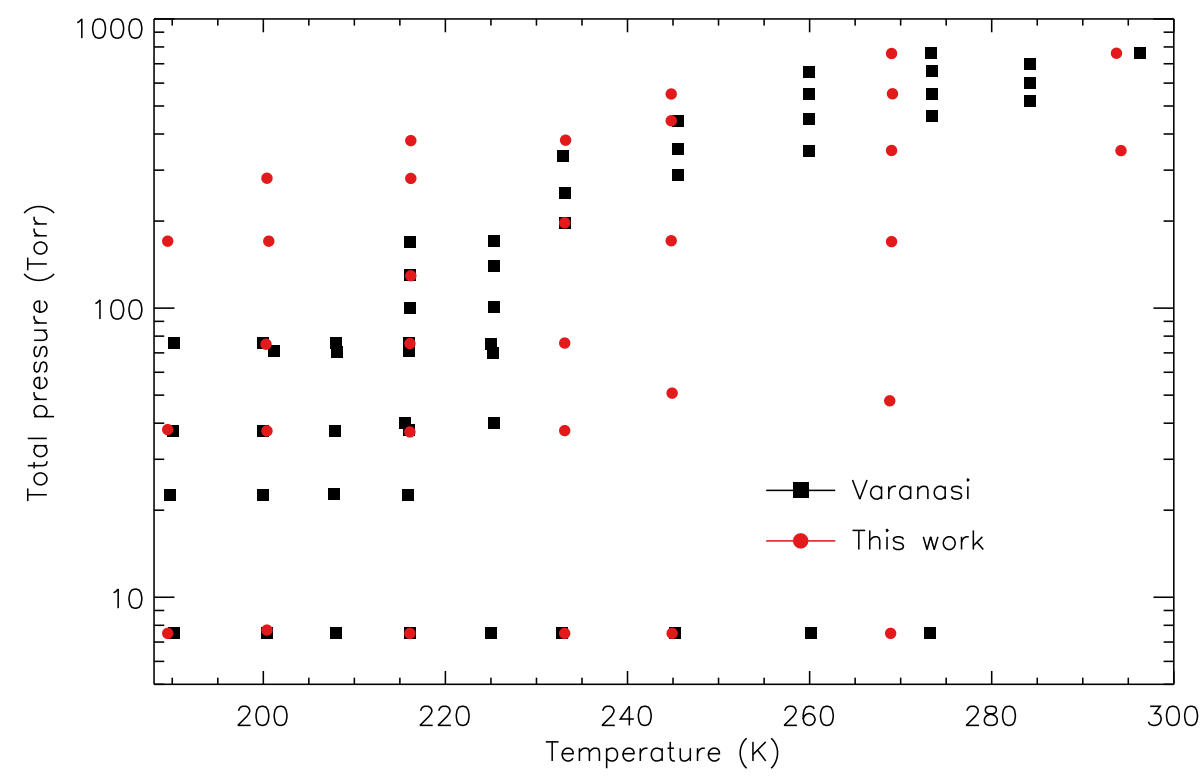

Figure 5. A graphical representation of the PT coverage for both the new and Varanasi datasets. Although the new dataset contains fewer individual IR absorption cross sections (32), it has been optimised to provide a more balanced dataset with wider PT coverage.

at lower and higher $P$. This means that the PT combinations within the dataset must cover all possible combinations of pressure and temperature appropriate for the region of the atmosphere being observed. Of the $52 \mathrm{PT}$ combinations in the Varanasi cross-section dataset, five are essentially redundant because they double up other measurements. There are also many PT combinations at relatively high temperature and high pressure, more than are strictly necessary. It has also been noted (C. D. Boone, personal communication, 2012) that the Varanasi dataset does not cover a wide enough range of pressures and temperatures to allow for the four-point interpolation scheme outlined earlier to always be used, thus contributing to errors in retrieved $\mathrm{CFC}-12$ mixing ratios. The new dataset presented in this work has extended the PT coverage to resolve this problem. Due to time constraints, however, it has been necessary to optimise the new dataset to just 32 PT combinations. Figure 5 provides a graphical representation of the PT combinations for both datasets.

In summary, compared to the previous dataset of Nemtchinov and Varanasi (Varanasi and Nemtchinov, 1994; Rothman et al., 2003), the new dichlorodifluoromethane absorptioncross-section dataset covers a wider range of pressures and temperatures, has a more accurately calibrated wavenumber scale, has more consistent integrated band intensities, exhibits no discernible channel fringes, and on average possesses improved SNR; it will therefore provide a more accurate basis for retrieving CFC-12 abundances from atmospheric spectra. Preliminary ACE-FTS retrievals for the upcoming v4.0 indicate an improvement in the $1 \sigma$ retrieval errors; a more detailed investigation of these improvements will follow at a later date.
Since CFC-12 is a relatively strong absorber in the atmosphere, particularly in the limb, this new cross-section dataset will also enable improved retrievals for other molecules for which their spectral features overlap, e.g. CFC-113 (C. D. Boone, personal communication, 2012). This new dataset is available electronically from the author and will be made available to the community via the HITRAN and GEISA databases.

\section{Conclusions}

New high-resolution IR absorption cross sections for dichlorodifluoromethane have been determined over the wavenumber range $800-1270 \mathrm{~cm}^{-1}$, with an estimated uncertainty of $3 \%$. Spectra were recorded for mixtures of dichlorodifluoromethane with dry synthetic air in a $26 \mathrm{~cm}$ pathlength cell at resolutions between 0.01 and $0.03 \mathrm{~cm}^{-1}$ (calculated as 0.9/MOPD) over a range of temperatures and pressures appropriate for upper troposphere-lower stratosphere conditions. Intensities were calibrated against dichlorodifluoromethane spectra in the PNNL IR database. These cross sections greatly improve upon those currently available in the HITRAN and GEISA databases and will enable accurate retrievals of CFC- 12 abundances from atmospheric spectra recorded by satellite-borne IR remotesensing instruments. 
Acknowledgements. The author wishes to thank the National Centre for Earth Observation (NCEO), funded by the UK Natural Environment Research Council (NERC), for supporting this work and for access to the Molecular Spectroscopy Facility (MSF) at the Rutherford Appleton Laboratory (RAL); R. G. Williams and R. A. McPheat for providing technical support at the RAL; and J. J. Remedios for assistance in accessing the MSF.

Edited by: L. Hoffmann

\section{References}

Bernath, P. F., McElroy, C. T., Abrams, M. C., Boone, C. D., Butler, M., Camy-Peyret, C., Carleer, M., Clerbaux, C., Coheur, P.F., Colin, R., DeCola, P., DeMazière, M., Drummond, J. R., Dufour, D., Evans, W. F. J., Fast, H., Fussen, D., Gilbert, K., Jennings, D. E., Llewellyn, E. J., Lowe, R. P., Mahieu, E., McConnell, J. C., McHugh, M., McLeod, S. D., Michaud, R., Midwinter, C., Nassar, R., Nichitiu, F., Nowlan, C., Rinsland, C. P., Rochon, Y. J., Rowlands, N., Semeniuk, K., Simon, P., Skelton, R., Sloan, J. J., Soucy, M.-A., Strong, K., Tremblay, P., Turnbull, D., Walker, K. A., Walkty, I., Wardle, D. A., Wehrle, V., Zander, R., and Zou, J.: Atmospheric Chemistry Experiment (ACE): mission overview, Geophys. Res. Lett., 32, L15S01, doi:10.1029/2005GL022386, 2005.

Bingham, G. E., Zhou, D. K., Bartschi, B. Y., Anderson, G. P., Smith, D. R., Chetwynd, J. H., and Nadile, R. M.: Cryogenic Infrared Radiance Instrumentation for Shuttle (CIRRIS 1A) earth limb spectral measurements, calibration, and atmospheric $\mathrm{O}_{3}$, $\mathrm{HNO}_{3}, \mathrm{CFC}-12$, and CFC-11 profile retrieval, J. Geophys. Res., 102, 3547-3558, 1997.

Brown, A. T., Volk, C. M., Schoeberl, M. R., Boone, C. D., and Bernath, P. F.: Stratospheric lifetimes of CFC-12, $\mathrm{CCl}_{4}, \mathrm{CH}_{4}$, $\mathrm{CH}_{3} \mathrm{Cl}$ and $\mathrm{N}_{2} \mathrm{O}$ from measurements made by the Atmospheric Chemistry Experiment-Fourier Transform Spectrometer (ACEFTS), Atmos. Chem. Phys., 13, 6921-6950, doi:10.5194/acp-136921-2013, 2013.

Carpenter, L. J. and Reimann, S. (Lead Authors), Burkholder, J. B., Clerbaux, C., Hall, B. D., Hossaini, R., Laube, J. C., and YvonLewis, S. A.: Ozone-Depleting Substances (ODSs) and other gases of interest to the Montreal Protocol, chapter 1, in: Scientific Assessment of Ozone Depletion: 2014, Global Ozone Research and Monitoring Project - Report No. 55, World Meteorological Organization, Geneva, Switzerland, 2014.

Chang, A. Y., Salawitch, R. J., Michelsen, H. A., Gunson, M. R., Abrams, M. C., Zander, R., Rinsland, C. P., Elkins, J. W., Dutton, G. S., Volk, C. M., Webster, C. R., May, R. D., Fahey, D. W., Gao, R.-S., Loewenstein, M., Podolske, J. R., Stimpfle, R. M., Kohn, D. W., Proffitt, M. H., Margitan, J. J., Chan, K. R., Abbas, M. M., Goldman, A., Irion, F. W., Manney, G. L., Newchurch, M. J., and Stiller, G. P.: A comparison of measurements from ATMOS and instruments aboard the ER-2 aircraft: halogenated gases, Geophys. Res. Lett., 23, 2393-2396, 1996.

Clerbaux, C. and Cunnold, D. M. (Lead Authors), Anderson, J., Engel, A., Fraser, P. J., Mahieu, E., Manning, A., Miller, J., Montzka, S. A., Nassar, R., Prinn, R., Reimann, S., Rinsland, C. P., Simmonds, P., Verdonik, D., Weiss, R., Wuebbles, D., and Yokouchi, Y.: Long-lived compounds, chapter 1, in: Scien- tific Assessment of Ozone Depletion: 2006, Global Ozone Research and Monitoring Project - Report No. 50, World Meteorological Organization, Geneva, Switzerland, 2007.

D’Amico, G., Snels, M., Hollenstein, H., and Quack, M. Analysis of the $v_{3}+v_{7}$ combination band of $\mathrm{CF}_{2} \mathrm{Cl}_{2}$ from spectra obtained by high resolution diode laser and FTIR supersonic jet techniques, Phys. Chem. Chem. Phys., 4, 1531-1536, 2002.

Dinelli, B. M., Arnone, E., Brizzi, G., Carlotti, M., Castelli, E., Magnani, L., Papandrea, E., Prevedelli, M., and Ridolfi, M.: The MIPAS2D database of MIPAS/ENVISAT measurements retrieved with a multi-target 2-dimensional tomographic approach, Atmos. Meas. Tech., 3, 355-374, doi:10.5194/amt-3-355-2010, 2010.

Harris, N. R. P. and Wuebbles, D. J. (Lead Authors), Daniel, J. S., Hu, J., Kuijpers, L. J. M., Law, K. S., Prather, M. J., and Schofield, R.: Scenarios and information for policymakers, chapter 5, in: Scientific Assessment of Ozone Depletion: 2014, Global Ozone Research and Monitoring Project - Report No. 55, World Meteorological Organization, Geneva, Switzerland, 2014.

Harrison, J. J.: Infrared absorption cross sections for trifluoromethane, J. Quant. Spectrosc. Ra., 130, 359-364, doi:10.1016/j.jqsrt.2013.05.026, 2013.

Harrison, J. J.: New and improved infrared spectroscopy of halogencontaining species for ACE-FTS retrievals, The 13th Biennial HITRAN Conference, Cambridge, Massachusetts, USA, 23-25 June 2014, doi:10.5281/zenodo.11114, 2014.

Harrison, J. J.: Infrared absorption cross sections for 1,1,1,2tetrafluoroethane, J. Quant. Spectrosc. Ra., 151, 210-216, doi:10.1016/j.jqsrt.2014.09.023, 2015.

Harrison, J. J., Allen. N. D. C., and Bernath, P. F.: Infrared absorption cross sections for ethane $\left(\mathrm{C}_{2} \mathrm{H}_{6}\right)$ in the $3 \mu \mathrm{m}$ region, $\mathrm{J}$. Quant. Spectrosc. Ra., 111, 357-363, 2010.

Hoffmann, L., Spang, R., Kaufmann, M., and Riese, M.: Retrieval of CFC-11 and CFC-12 from Envisat MIPAS observations by means of rapid radiative transfer calculations, Adv. Space Res., 36, 915-921, doi:10.1016/j.asr.2005.03.112, 2005.

Hoffmann, L., Hoppe, C. M., Müller, R., Dutton, G. S., Gille, J. C., Griessbach, S., Jones, A., Meyer, C. I., Spang, R., Volk, C. M., and Walker, K. A.: Stratospheric lifetime ratio of CFC-11 and CFC-12 from satellite and model climatologies, Atmos. Chem. Phys., 14, 12479-12497, doi:10.5194/acp-14-12479-2014, 2014.

Irion, F. W., Gunson, M. R., Toon, G. C., Chang, A. Y., Eldering, A., Mahieu, E., Manney, G. L., Michelsen, H. A., Moyer, E. J., Newchurch, M. J., Osterman, G. B., Rinsland, C. P., Salawitch, R. J., Sen, B., Yung, Y. L., and Zander, R.: Atmospheric Trace Molecule Spectroscopy (ATMOS) experiment version 3 data retrievals, Appl. Optics, 41, 6968-6979, 2002.

Jacquinet-Husson, N., Scott, N. A., Chédin, A., Garceran, K., Armante, R., Chursin, A. A., Barbe, A., Birk, M., Brown, L. R., Camy-Peyret, C., Claveau, C., Clerbaux, C., Coheur, P. F., Dana, V., Daumont, L., Debacker-Barilly, M. R., Flaud, J. M., Goldman, A., Hamdouni, A., Hess, M., Jacquemart, D., Köpke, P., Mandin, J. Y., Massie, S., Mikhailenko, S., Nemtchinov, V., Nikitin, A., Newnham, D., Perrin, A., Perevalov, V. I., Régalia-Jarlot, L., Rublev, A., Schreier, F., Schult, I., Smith, K. M., Tashkun, S. A., Teffo, J. L., Toth, R. A., Tyuterev, V. G., Vander Auwera, J., Varanasi, P., and Wagner, G.: The 2003 edition of the GEISA/IASI spectroscopic database, J. Quant. Spectrosc. Ra., 95, 429-467, 2005. 
Jacquinet-Husson, N., Crepeau, L., Armante, R., Boutammine, C., Chédin, A., Scott, N. A., Crevoisier, C., Capelle, V., Boone, C., Poulet-Crovisier, N., Barbe, A., Campargue, A., Benner, D. C., Benilan, Y., Bézard, B., Boudon, V., Brown, L. R., Coudert, L. H., Coustenis, A., Dana, V., Devi, V. M., Fally, S., Fayt, A., Flaud, J.-M., Goldman, A., Herman, M., Harris, G. J., Jacquemart, D., Jolly, A., Kleiner, I., Kleinböhl, A., Kwabia-Tchana, F., Lavrentieva, N., Lacome, N., Xu, L.-H., Lyulin, O. M., Mandin, J.-Y., Maki, A., Mikhailenko, S., Miller, C. E., Mishina, T., Moazzen-Ahmadi, N., Müller, H. S. P., Nikitin, A., Orphal, J., Perevalov, V., Perrin, A., Petkie, D. T., Predoi-Cross, A., Rinsland, C. P., Remedios, J. J., Rotger, M., Smith, M. A. H., Sung, K., Tashkun, S., Tennyson, J., Toth, R. A., Vandaele, A.-C., and Vander Auwera, J.: The 2009 edition of the GEISA spectroscopic database, J. Quant. Spectrosc. Ra., 112, 2395-2445, 2011.

Kagann, R. H., Elkins, J. W., and Sams, R. L.: Absolute band strengths of halocarbons F-11 and F-12 in the 8- to $16-\mu \mathrm{m}$ region, J. Geophys. Res., 88, 1427-1432, 1983.

Kellmann, S., von Clarmann, T., Stiller, G. P., Eckert, E., Glatthor, N., Höpfner, M., Kiefer, M., Orphal, J., Funke, B., Grabowski, U., Linden, A., Dutton, G. S., and Elkins, J. W.: Global CFC-11 $\left(\mathrm{CCl}_{3} \mathrm{~F}\right)$ and CFC-12 $\left(\mathrm{CCl}_{2} \mathrm{~F}_{2}\right)$ measurements with the Michelson Interferometer for Passive Atmospheric Sounding (MIPAS): retrieval, climatologies and trends, Atmos. Chem. Phys., 12, 11857-11875, doi:10.5194/acp-12-118572012, 2012.

Khosrawi, F., Müller, R., Irie, H., Engel, A., Toon, G. C., Sen, B., Aoki, S., Nakazawa, T., Traub, W. A., Jucks, K. W., Johnson, D. G., Oelhaf, H., Wetzel, G., Sugita, T., Kanzawa, H., Yokota, T., Nakajima, H., and Sasano, Y.: Validation of CFC-12 measurements from the Improved Limb Atmospheric Spectrometer (ILAS) with the version 6.0 retrieval algorithm, J. Geophys. Res., 109, D06311, doi:10.1029/2003JD004325, 2004.

Massie, S. T. and Goldman, A.: Absorption parameters of very dense molecular spectra for the HITRAN compilation, J. Quant. Spectrosc. Ra., 48, 713-719, 1992.

Massie, S. T., Goldman, A., Murcray, D. G., and Gille, J. C.: Approximate absorption cross-sections of F12, F11, $\mathrm{ClONO}_{2}$, $\mathrm{N}_{2} \mathrm{O}_{5}, \mathrm{HNO}_{3}, \mathrm{CCl}_{4}, \mathrm{CF}_{4}, \mathrm{~F} 21, \mathrm{~F} 113, \mathrm{~F} 114$, and $\mathrm{HNO}_{4}$, Appl. Optics, 24, 3426-3427, 1985.

McDaniel, A. H., Cantrell, C. A., Davidson, J. A., Shetter, R. E., and Calvert, J. G.: The temperature dependent, infrared absorption cross-sections for the chlorofluorocarbons: CFC-11, CFC12, CFC-13, CFC-14, CFC-22, CFC-113, CFC-114, and CFC115, J. Atmos. Chem., 12, 211-227, 1991.

McNaughton, D., McGilvery, D., and Robertson, E. G.: Highresolution FTIR-Jet Spectroscopy of $\mathrm{CCl}_{2} \mathrm{~F}_{2}$, J. Chem. Soc. Faraday Trans., 90, 1055-1060, 1994.

Molina, M. J. and Rowland, F. S.: Stratospheric sink for chlorofluoromethanes: chlorine atom-catalyzed destruction of ozone, Nature, 249, 810-812, 1974.

Myers, R. L.: The 100 Most Important Chemical Compounds: A Reference Guide, Greenwood Press, Westport, Connecticut, USA, 2007.

Nguyen, V.-T., Rossi, I., and Jean-Louis, A.: Infrared bandshapes and band strengths of $\mathrm{CF}_{2} \mathrm{Cl}_{2}$ from 800 to $1200 \mathrm{~cm}^{-1}$ at 296 and 200 K, J. Geophys. Res., 91, 4056-4062, 1986.
Nightingale, R. W., Roche, Q. E., Kumer, J. B., Mergenthaler, J. L., Gille, J. C., Massie, S. T., Bailey, P. L., Edwards, D. P., Gunson, M. R., Toon, G. C., Sen, B., Blavier, J.-F., and Connell, P. S.: Global $\mathrm{CF}_{2} \mathrm{Cl}_{2}$ measurements by UARS cryogenic limb array etalon spectrometer: validation by correlative data and a model, J. Geophys. Res., 101, 9711-9736, 1996.

Offermann, D., Grossmann, K.-U., Barthol, P., Knieling, P., Riese, M., and Trant, R.: Cryogenic Infrared Spectrometers and Telescopes for the Atmosphere (CRISTA) experiment and middle atmosphere variability, J. Geophys. Res., 104, 16311-16325, doi:10.1029/1998JD100047, 1999.

Rees, J.: Refrigeration Nation: a History of Ice, Appliances, and Enterprise in America, Johns Hopkins University Press, Baltimore, Maryland, USA, 2013.

Rothman, L. S., Gamache, R. R., Goldman, A., Brown, L. R., Toth, R. A., Pickett, H. M., Poynter, R. L., Flaud, J.-M., Camy-Peyret, C., Barbe, A., Husson, N., Rinsland, C. P., and Smith, M. A. H.: The HITRAN database: 1986 edition, Appl. Optics, 26, 4058-4097, 1987.

Rothman, L. S., Gamache, R. R., Tipping, R. H., Rinsland, C. P., Smith, M. A. H., Benner, D. C., Devi, V.M, Flaud, J.-M., CamyPeyret, C., Perrin, A., Goldman, A., Massie, S. T., Brown, L. R., and Toth, R. A.: The HITRAN molecular database: editions of 1991 and 1992, J. Quant. Spectrosc. Ra., 48, 469-507, 1992.

Rothman, L. S., Rinsland, C. P., Goldman, A., Massie, S. T., Edwards, D. P., Flaud, J- M., Perrin, A., Camy-Peyret, C., Dana, V., Mandin, J.-Y., Schroeder, J., Mccann, A., Gamache, R. R., Wattson, R. B., Yoshino, K., Chance, K. V., Jucks, K. W., Brown, L. R., Nemtchinov, V., and Varanasi, P.: The HITRAN molecular spectroscopic database and Hawks (HITRAN Atmospheric Workstation): 1996 edition, J. Quant. Spectrosc. Ra., 60, 665-710, 1998.

Rothman, L. S., Barbe, A., Benner, D. C., Brown, L. R., Camy-Peyret, C., Carleer, M. R., Chance, K., Clerbaux, C., Dana, V., Devi, V. M., Fayt, A., Flaud, J.-M., Gamache, R. R., Goldman, A., Jacquemart, D., Jucks, K. W., Lafferty, W. J., Mandin, J.-Y., Massie, S. T., Nemtchinov, V., Newnham, D. A., Perrin, A., Rinsland, C. P., Schroeder, J., Smith, K. M., Smith, M. A. H., Tang, K., Toth, R. A., Vander Auwera, J., Varanasi, P., and Yoshino, K.: The HITRAN molecular spectroscopic database: edition of 2000 including updates through 2001, J. Quant. Spectrosc. Ra., 82, 5-44, 2003.

Rothman, L. S., Gordon, I. E., Babikov, Y., Barbe, A., Benner, D. C., Bernath, P. F., Birk, M., Bizzocchi, L., Boudon, V., Brown, L. R., Campargue, A., Chance, K., Cohen, E. A., Coudert, L. H., Devi, V. M., Drouin, B. J., Fayt, A., Flaud, J.M., Gamache, R. R., Harrison, J. J., Hartmann, J.-M., Hill, C., Hodges, J. T., Jacquemart, D., Jolly, A., Lamouroux, J., Le Roy, R. J., Li, G., Long, D. A., Lyulin, O. M., Mackie, C. J., Massie, S. T., Mikhailenko, S., Müller, H. S. P., Naumenko, O. V., Nikitin, A. V., Orphal, J., Perevalov, V., Perrin, A., Polovtseva, E. R., Richard, C., Smith, M. A. H., Starikova, E., Sung, K., Tashkun, S., Tennyson, J., Toon, G. C., Tyuterev, V. G., and Wagner, G.: The HITRAN2012 molecular spectroscopic database, J. Quant. Spectrosc. Ra., 130, 4-50, 2013.

Sharpe, S. W., Johnson, T. J., Sams, R. L., Chu, P. M., Rhoderick, G. C., and Johnson, P. A.: Gas-phase databases for quantitative infrared spectroscopy, Appl. Spectrosc., 58, 1452-1461, 2004. 
Solomon, S.: Stratospheric ozone depletion: a review of concepts and history, Rev. Geophys., 37, 275-316, 1999.

Varanasi, P. and Chudamani, S.: Infrared intensities of some chlorofluorocarbons capable of perturbing the global climate, J. Geophys. Res., 93, 1666-1668, 1988.

Varanasi, P. and Ko, F.-K.: Intensity measurements in freon bands of atmospheric interest, J. Quant. Spectrosc. Ra., 17, 385-388, 1977.

Varanasi, P. and Nemtchinov, V.: Thermal infrared absorption coefficients of CFC-12 at atmospheric conditions, J. Quant. Spectrosc. Ra., 51, 679-681, 1994.
Wetzel, G., Oelhaf, H., Friedl-Vallon, F., Kleinert, A., Lengel, A., Maucher, G., Nordmeyer, H., Ruhnke, R., Nakajima, H., Sasano, Y., Sugita, T., and Yokota, T.: Intercomparison and validation of ILAS-II version 1.4 target parameters with MIPAS-B measurements, J. Geophys. Res., 111, D11S06, doi:10.1029/2005JD006287, 2006.

Williscroft, C. (Ed.): A Lasting Legacy: A 125 Year History of New Zealand Farming Since the First Frozen Meat Shipment, NZ Rural Press, Auckland, New Zealand, 2007. 